\title{
The Structures which Control the Location of Kimberlites of Middle-Markhinsky Region
}

Zuev, V.M.', Bezborodov, S.M.', Chyerny, S.D. ${ }^{1}$, Yanygin, Y.T.', Molchanov, Y.D.', Ignatov, P.A. ${ }^{2}$, Shtein, Y.I. ${ }^{2}$

1. ALROSA Co. Ltd., Lenin St. 6, Mirny, 678170, Sakha (Yakutia), Russia

2. MGGA

The structure of Middle-Markhinsky region is determined by large tectonic intersection knot of the first order faults' branches - Vilyuy-Markhinsky dike belt of north-eastern stretch and transverse to it zone of paleolifts. The first of the named zones of faults is the marginal one in middlePaleozoic rift system (Gaiduk, 1987, et al.).

The structure of a kimberlite field. A tectonic block of $20 \times 30 \mathrm{~km}$ size, divided by faults in its turn into two approximately equal blocks, is considered as a kimberlite field (Fig. 1).

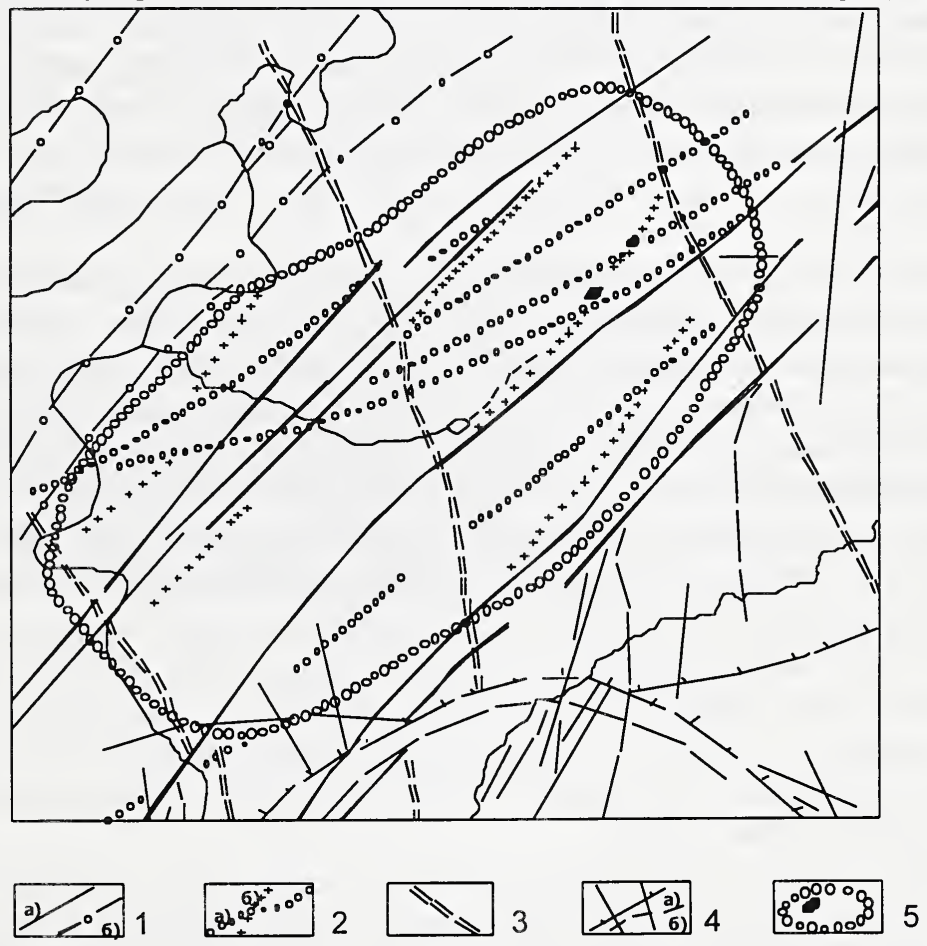

Fig. 1. Structural scheme of Nakynsky field

Faults of Vilyuy-Markhinsky tectonic zone of north-eastern stretch performed by dikes of trapps:

1. 1st order: a - central part (of axial branch) of the zone; $\sigma$ - flank (side) branches of the zone.

2. 2nd and 3rd order: a - controlling kimberlite; 6 - supposed ore-hosting, hidden, with fragmentary manifestation in geophysical fields.

3. Faults of Middle-Markhinsky tectonic zone of north-western stretch. 
4. Contours of subhorizontal intrusions of trapps at different levels in sedimentary cover - a; their circular and radial apophysises (of dike type) - 6 .

5. Kimberlite pipes and probable contour of a kimberlite field.

The blocks are limited by relatively large zones of orthogonal faults. The faults are clearly distinguished by the results of structural interpretation of surface magnetic and gravitational fields, as well as by airborne magnetic data. They have north-eastern and north-western stretch. The first faults are more prolonged and rectilinear. The second ones - are often interrupted and represented both by individual arched in the plan links and their rectilinear diversities.

The faults of both directions are performed by steeply dipping dikes of dolerites, by clearly expressed contrast linear positive anomalies of magnetic and gravitational fields. North-eastern violations represent individual branches of gigantic system both in prolonged and in transverse directions of faults of Vilyuy-Markhinsky dike belt of middle-Paleozoic age. The tectonic block under discussion is in the axial part of the belt.

The faults of north-western stretch are more late with regard to the main north-eastern ones. At least their performance by basic magma took place after coming into being of the main faults of north-eastern direction. This is well seen by the elements of screening and their shifting by northeastern faults, availability in them of dikes' swells with approaching to north-eastern tectonic borders or their bend (the change of the stretch) in tangent to the latter ones. All such features of faults' relationship are well traced in magnetic field. Faults of much higher orders take place inside the block.

The structure of the ore knot of the Botuobinskaya and Nyurbinskaya kimberlite pipes.

These pipes are located in three kilometres from each other, they have close to each other composition, and evidently form the unified ore knot of kimberlites. Within the limits of close to the pipe space in the hosting sedimentary thick layers there have been mapped the indications of explosive (bursting) violations. They have steep dip, different stretch and mainly are hidden.

The main ore-hosting structure of this area is represented by the extended to several kilometres hidden fault of north-north-eastern stretch. Two relatively large tectonic sutures are earmarked in its composition. In the flexure fold of one of them Botuobinsky deposit is located. These violations are located in subparallel in the distance of $350 \mathrm{~m}$ from each other. They are mapped according to the materials of the detailed exploration of core of hosting sedimentary thick layers according to the inumerated below indications, as well as according to interpretation of low-amplitude anomalies of magnetic field. The revealed ore-hosting fault structure should be considered as the violation of the fourth order. It is diagonal in relation to interblock faults which limit the kimberlite field and to controlling the ore faults.

Within the cluster there are several east-north-eastern tectonic sutures which are revealed by boring data and during interpretation of large-scale magnetic and gravity field. In the magnetic field they are represented by sufficiently extended (tens of $\mathrm{km}$ ) linear positive anomalies of various width and intensity. Such sublatitudinal faults are described as much larger ones, of the 3rd order, and subparallel to them, less expressed - as violations of much higher order.

The Nyurbinskaya pipe is localized in tectonic intersection knot of small tectonic sutures, which are subparallel to the faults of Vilyuy-Markhinsky dike belt and the basic zone of north-northeastern stretch. Indications of these faults are sufficiently distinctly established in the nearest exocontact of the kimberlite field. Here, as well as on the site of the Botuobinskaya pipe, submeridianal bend outlines in the plan of this ore-controlling fault.

The deposit's structure. The Botuobinsky deposit is composed by two phases of kimberlite. The earlier phase is represented by a dike body of autolithic porphyritic kimberlites, which has north- 
north-eastern stretch and steep west-north-western dip. The later phase of explosive kimberlite breccias composes a typical pipe with subvertical axis extended in the plan in the same direction. These kimberlites are located to the north of the dike and cross it.

By the data of detailed investigation of the core of hosting kimberlites pipes of early-Paleozoic age terrigenous-carbonate sedimentary rocks the indications of tectonic violations controlling disposition of ore columns are established. Those indications are: microbreccias; sharp alterations of subhorizontal layers' occurrence; microbreaks; drawn together steeply dipping veins executed by calcite, pyrite, seldom by dolomite; tectonic cleavage; slickensided surfaces, textures of clastic dikes' type.

The tectonic suture of north-north-eastern stretch, having subvertical and steep dip, is traced with certainty by these indications. In the plan this fault has distinct flexure bend which is seen in the section as well. Besides the main fault there are small feathering violations of submeridianal and north-eastern stretch located in the heading side of the main suture.

It is the flexure bend of the revealed fault that both phases of kimberlites are attributed to. Both the dike and the pipe are located in south-eastern part of the suture. The dike of porphyritic autolithic kimberlites represents the wing of the fault's flexure. Breccial kimberlites of the diatreme take up regular position in the complicated tectonic knot located in the heading side of the main fault. In connection with this one can suppose that the revealed rupture violations were mainly formed in pre-ore stages. And in the making of kimberlites they renovated and served as channels of ultrabasites' penetration.

The new thing in this case is attribution of kimberlite pipes to flexure bends (breaks) of local hidden in sedimentary cover tectonic sutures. This, together with the outlined main ore-controlling zone of the fault serve as the basis for forecasting new kimberlite bodies within the cluster. They can be localized in the knots of intersection and morphological complications of the revealed tectonic sutures of north-north-eastern stretch.

Thus, kimberlite bodies of new Middle-Markhinsky region are controlled by the sites of intersection and morphological complications of the faults of the fourth and much higher orders. The revealed kimberlite cluster is related with diagonal fault of the third order, and Nakyn field with intersection knot of the second order rupture violations. 